\title{
Magnitude of Construction Cost and Schedule Overruns in Public Work Projects
}

\author{
Pramen P. Shrestha, ${ }^{1}$ Leslie A. Burns, ${ }^{2}$ and David R. Shields ${ }^{1}$ \\ ${ }^{1}$ Department of Civil \& Environmental Engineering \& Construction, Howard R. Hughes College of Engineering, \\ University of Nevada, Las Vegas, NV 89154, USA \\ ${ }^{2}$ Clark County Public Works Department, Las Vegas, NV 89154, USA
}

Correspondence should be addressed to Pramen P. Shrestha; pramen.shrestha@unlv.edu

Received 3 April 2013; Accepted 19 October 2013

Academic Editor: Manoj Jha

Copyright (C) 2013 Pramen P. Shrestha et al. This is an open access article distributed under the Creative Commons Attribution License, which permits unrestricted use, distribution, and reproduction in any medium, provided the original work is properly cited.

This study analyzed 363 Clark County Department of Public Works (CCDPW) projects to determine construction cost and schedule overruns in various types and sizes of the projects. The sample projects were constructed from 1991 to 2008 , with a total construction cost of $\$ 1.85$ billion, equivalent to 2012 cost. A one-factor ANOVA test was conducted to determine whether construction cost and schedule overruns significantly varied based on types and sizes of the projects. The study showed that large, long-duration projects had significantly higher cost and schedule overruns than smaller, short-duration projects.

\section{Introduction}

Consistent cost and time overruns of public works projects are not the best use of taxpayer money. In the current economic downturn where tax revenues are lagging, they are particularly detrimental. In the public sector, money spent on project change orders and increased construction time reduces the number and size of the projects that can be completed during any given fiscal year.

Various reasons for construction cost and schedule overruns in any project include design error, inadequate scope, weather, project changes, and underestimating the time needed to complete the project. Items omitted from the engineer's estimate of the projects due to design errors or inadequate scope frequently result in change orders, which increase cost as well as the time of delivery. Underestimating the construction time is detrimental because another important project may be delayed from going to bid until the current project is completed. Many public projects are extensions of a previous project, and inaccuracies in estimating project cost and construction time can result in improper sequencing of related projects or phasing within projects, thus delaying much needed improvements.
Decisions on which projects are to put out for bids are based both on the need for improvement in a current facility or construction of a new facility, which is certainly the most important consideration, and on the engineer's estimated cost and construction time. Underestimating a project's cost and time is not in the public's best interest, particularly in an urban area with a rate of growth such as the one recently experienced in Clark County, Nevada. Therefore, this study determined the magnitude of construction cost and schedule overruns in public projects of Clark County, Nevada, so that necessary actions can be taken to control these overruns in future projects. Further, the study investigated whether the magnitude of construction cost and schedule overruns varies based on types and size of the projects, as found by previous researchers [1-3].

The objectives of this paper are to (1) provide additional data on the magnitude of cost and schedule overruns in public work projects and (2) determine the difference in the magnitude of overruns based on project type, project size, construction duration, and construction completion time. This study will examine construction cost and schedule overruns of projects constructed by the Clark County Department of Public Works (CCDPW) in Clark County, Nevada, from 
TABLE 1: Factors influencing the percent change in contract cost for public work projects (Randolph et al., 1987) [3].

\begin{tabular}{lccc}
\hline Independent variables & \multicolumn{3}{c}{ Contract cost change } \\
& $\begin{array}{c}\text { No. of } \\
\text { projects }\end{array}$ & $\begin{array}{c}\text { Correlation } \\
\text { coefficient }\end{array}$ & $\begin{array}{c}\text { Significance } \\
\text { value }\end{array}$ \\
\hline $\begin{array}{l}\text { Name of the } \\
\text { contractor }\end{array}$ & 119 & 0.72 & $0.020^{*}$ \\
$\begin{array}{l}\text { Type of work } \\
\text { performed }\end{array}$ & 119 & 0.97 & $0.020^{*}$ \\
$\begin{array}{l}\text { Number of unit cost } \\
\text { items in bid }\end{array}$ & 119 & 0.97 & $0.026^{*}$ \\
\hline
\end{tabular}

${ }^{*}$ Significant at alpha level 0.05 .

1991 to 2008. The differences between the awarded and the actual cost and schedule are presented as a construction cost and schedule overruns, which is a percentage increase of the award cost and schedule. In this study, 363 public works construction projects were analyzed.

\section{Literature Review}

Randolph et al. [3] conducted a study to determine the factors influencing the percent change in contract cost for public work projects; this was expressed in terms of a percentage deviation from an average contract cost. Data were collected for 119 projects, contracted by the Public Service Department of Lansing, Michigan, from 1977 to 1985. Street, sewer, sidewalk, bridge repair, painting, and demolition projects were included in this study. The size of the projects was classified as small (less than $\$ 50,000$ bid cost), medium (\$50,000-\$250,000 bid cost), and large (more than $\$ 250,000$ bid cost). The factors considered for analysis were bid year, type of work, number of unit cost items in bid, funding source of project, job classification, project designer, and the name of the contractor.

Table 1, which displays the results of the correlation analysis for this group's study, shows that the percentage change in contract cost was higher in some contractors than in others. Similarly, sewer construction had the highest percentage change in contract cost, and sidewalk repair had the lowest. The authors explained the reasons for this as the "... inability of the contractors to fully anticipate soil conditions that affect sewer construction techniques and production. This uncertainty causes them to bid a much wider range of costs ..." [3].

Additionally, this study indicated that the higher the number of unit cost items in the bid, the higher the percentage change in contract cost. The authors pointed out that one possible explanation for this was that the contract that had a higher number of unit cost items was supposed to be a complex project. Further, the study found that smaller projects had a higher percentage change in project cost [3]. This study did not determine whether the name of the contractor was correlated with the type of construction, which raises the question of whether the percentage change in contract cost was due to the type of contractors or due to the type of construction.
Jahren and Ashe [1] conducted research to identify the predictors of cost-overrun rates on Naval Facilities Engineering Command (NAVFAC) construction projects. The sample size of this study was 1,576 projects. The authors calculated the cost overruns to be the percentage increase of the construction cost with respect to the construction award cost. The predictors considered for this analysis were the size of the project and the difference between the low bid and the government estimate. The project size was divided into four categories: $\$ 25,000$ to $\$ 75,000, \$ 75,000$ to $\$ 200,000, \$ 200,000$ to $\$ 1$ million, and more than $\$ 1$ million. The authors used descriptive statistics to determine the cost overruns on these four types of project.

The results showed that the median cost-overrun ratesthe difference between final completion cost and the contract bid cost-for projects costing between $\$ 25,000$ to $\$ 75,000$, $\$ 75,000$ to $\$ 200,000, \$ 200,000$ to $\$ 1$ million, and more than $\$ 1$ million were $0.15 \%, 1.36 \%, 3.21 \%$, and $3.24 \%$, respectively. The study found that the cost-overrun rate was more likely to occur on larger projects than on smaller ones; these results were exactly opposite to the findings from Randolph et al. [3].

Out of 1,576 projects, the government estimates for only 41 projects were obtained from NAVFAC. The authors did not discuss the accuracy of the government estimates. They analyzed these project data in order to determine the correlation between the cost-overrun rate and the difference between low bid and the government estimate. The data were first divided into two groups. The first group consisted of contracts that had award amounts less than the government estimate. The second group consisted of contracts that had award amounts more than the government estimate. The chi-square test showed that the cost-overrun rate of contracts with award amounts less than the government estimate was significantly higher than that of contracts with award amounts more than the government estimate. According to Jahren and Ashe [1], "it was found that contracts with award amounts less than the government estimate were more likely to have cost-overrun rates above 5\%."

Research performed by Vidalis and Najafi [6] investigated causes for cost and schedule overruns in 708 highway projects for the Florida Department of Transportation, constructed between 1999 and 2001 with a combined original contract amount of over $\$ 1.9$ billion. A cost overrun was defined as a percentage difference between the final completion cost and the contract bid cost. A time overrun is the difference between construction bid duration and final completion duration, expressed in percentage of bid duration. The combined cost overrun for these projects was $\$ 200$ million, whereas the total time overrun was $17 \%$ of the original contract time. Moreover, the results showed that there was a decline in both cost and time overruns over the past five years. This was due to the introduction of new and innovative techniques, such as incentive/disincentive, lane rental, and $\mathrm{A}+\mathrm{B}$ contracting.

Further, the study identified the reasons for cost and time overruns in these projects. The data analysis showed that $39 \%$ of the projects' cost overruns were due to plans and modifications in the projects. About $34 \%$ of the projects cost overruns were caused by the changed conditions. Similarly, $29 \%$ of the projects' time overruns were due to the results 
TABLE 2: Findings from studies to correlate factors influencing cost and schedule overruns in construction projects.

\begin{tabular}{|c|c|c|c|c|}
\hline Researchers & $\begin{array}{c}\text { Number of } \\
\text { projects }\end{array}$ & Project types & Project size & Major findings \\
\hline $\begin{array}{l}\text { Randolph et al. } \\
\text { (1987) [3] }\end{array}$ & 119 & $\begin{array}{l}\text { Street, sewer, } \\
\text { sidewalk, bridge } \\
\text { repair, and so forth. }\end{array}$ & $\begin{array}{l}\text { Up to } \\
\$ 5 \mathrm{M}\end{array}$ & $\begin{array}{l}\text { Cost overruns were correlated with } \\
\text { the name of the contractor, type of } \\
\text { work, project size, and the number } \\
\text { of items in bid }\end{array}$ \\
\hline $\begin{array}{l}\text { Jahren and Ashe } \\
\text { (1990) [1] }\end{array}$ & 1,576 & $\begin{array}{c}\text { Naval Facilities } \\
\text { Engineering } \\
\text { Command } \\
\text { (NAVFAC) } \\
\text { construction projects }\end{array}$ & Over $\$ 1 \mathrm{M}$ & $\begin{array}{l}\text { Cost overruns were correlated with } \\
\text { the size of the project and the } \\
\text { difference between the low bid and } \\
\text { the government estimate }\end{array}$ \\
\hline Roth (1995) [4] & 12 & $\begin{array}{c}\text { Navy child care } \\
\text { facilities } \\
\end{array}$ & $\mathrm{N} / \mathrm{A}$ & $\begin{array}{c}\text { Cost overruns were less in DB } \\
\text { projects compared to DBB projects }\end{array}$ \\
\hline $\begin{array}{l}\text { Konchar and } \\
\text { Sanvido (1998) [5] }\end{array}$ & 271 & $\begin{array}{l}\text { Industrial and } \\
\text { building projects }\end{array}$ & $\mathrm{N} / \mathrm{A}$ & $\begin{array}{l}\text { Cost and schedule overruns were } \\
\text { fewer in DB projects than in DBB } \\
\text { projects }\end{array}$ \\
\hline $\begin{array}{l}\text { Vidalis and Najafi } \\
(2002)[6]\end{array}$ & 700 & Highway projects & $\begin{array}{l}\$ 40 \mathrm{~K} \text { to } \\
\$ 20 \mathrm{M}\end{array}$ & $\begin{array}{l}\text { Cost and schedule overruns were } \\
\text { correlated with design changes, } \\
\text { changed conditions, utility conflicts, } \\
\text { and weather damage delays }\end{array}$ \\
\hline Odeck (2004) [2] & 620 & Road projects & $\begin{array}{l}\text { Up to } \\
350 \mathrm{NOK}\end{array}$ & $\begin{array}{l}\text { Cost overruns were correlated with } \\
\text { the size, construction duration, and } \\
\text { location of the projects }\end{array}$ \\
\hline Lee (2008) [7] & 161 & $\begin{array}{l}\text { Road, rails, airports, } \\
\text { and ports projects }\end{array}$ & N/A & $\begin{array}{l}\text { The main reasons for cost overruns } \\
\text { were changes in scope, delays in } \\
\text { construction, inaccurate estimates, } \\
\text { and adjustment of project costs }\end{array}$ \\
\hline $\begin{array}{l}\text { Shrestha et al. } \\
(2007)[8]\end{array}$ & 11 & Highway projects & $\begin{array}{l}\$ 50 \mathrm{M} \text { to } \\
\$ 1.3 \mathrm{~B}\end{array}$ & $\begin{array}{l}\text { Cost overruns were lower in DB } \\
\text { projects than in DBB projects. } \\
\text { However, schedule overruns were } \\
\text { higher in DB projects than in DBB } \\
\text { projects }\end{array}$ \\
\hline Hale et al. (2009) [9] & 77 & $\begin{array}{l}\text { Navy bachelor's } \\
\text { enlisted quarters }\end{array}$ & N/A & $\begin{array}{l}\text { Cost and schedule overruns were } \\
\text { significantly lower in DB projects } \\
\text { than in DBB projects }\end{array}$ \\
\hline
\end{tabular}

TABLE 3: List of variables.

\begin{tabular}{lccl}
\hline No. & Variable & Type of scale & Explanation \\
\hline 1 & Type of project & Nominal & Either flood control, transportation, or utilities \\
2 & Year & Interval & Project completion year \\
3 & Engineer estimated cost & Ratio & Engineer's estimated cost of project \\
4 & Award cost & Ratio & Contract award cost of project \\
5 & Change orders & Ratio & Cost of change orders issued in the project \\
6 & Final cost & Ratio & Actual cost of the project \\
7 & Cost overrun (\%) & Interval & Difference between the actual and award cost divided by award cost \\
8 & Construction days awarded & Ratio & Days awarded to complete the project \\
9 & Construction days added & Ratio & Days added to complete the project \\
10 & Schedule overrun (\%) & Interval & Difference between actual and award days divided by award days \\
11 & Notice to proceed (NTP) date & Interval & Construction start date \\
12 & Substantial completion date & Interval & Construction completion date \\
13 & Size of project & Ratio & Size of the project, as measured by the class of the actual cost converted to a 2008 base cost \\
14 & Project construction duration & Ratio & Duration of the project, as measured by the class of the actual completion duration \\
15 & Project completion year & Interval & Project completion year, as measured by the class of the actual project completion date \\
\hline
\end{tabular}


TABLE 4: Mean and median values of construction cost overrun by project factors.

\begin{tabular}{|c|c|c|c|c|c|}
\hline \multirow{2}{*}{ Project factors } & \multirow{2}{*}{ Categories } & \multirow{2}{*}{ No. of projects } & \multicolumn{3}{|c|}{ Construction cost overrun (\%) } \\
\hline & & & Mean & Median & Standard deviation \\
\hline \multirow{3}{*}{ Project types } & Flood control & 83 & 3.04 & 0.00 & 8.87 \\
\hline & Transportation & 236 & 3.23 & 0.17 & 5.99 \\
\hline & Utilities & 44 & 1.27 & 0.00 & 4.33 \\
\hline \multirow{3}{*}{ Project size } & Less than $\$ 1$ million & 135 & 1.67 & 0.00 & 5.83 \\
\hline & $\$ 1$ million to $\$ 5$ million & 128 & 3.55 & 0.76 & 5.59 \\
\hline & Greater than $\$ 5$ million & 100 & 3.92 & 1.75 & 8.38 \\
\hline \multirow{2}{*}{ Project construction duration } & Less than 1 year & 279 & 2.46 & 0.00 & 5.85 \\
\hline & Greater than 1 year & 84 & 4.59 & 2.12 & 8.54 \\
\hline \multirow{2}{*}{ Project completion year } & From 1991 to 2000 & 185 & 2.66 & 0.00 & 6.69 \\
\hline & From 2001 to 2008 & 178 & 3.25 & 0.00 & 6.54 \\
\hline Total projects & & 363 & 2.95 & 0.00 & 6.62 \\
\hline
\end{tabular}

TABLE 5: Mean and median values of schedule overrun by project factors.

\begin{tabular}{|c|c|c|c|c|c|}
\hline \multirow{2}{*}{ Project factors } & \multirow{2}{*}{ Categories } & \multirow{2}{*}{ No. of projects } & \multicolumn{3}{|c|}{ Construction schedule overrun (\%) } \\
\hline & & & Mean & Median & Standard deviation \\
\hline \multirow{3}{*}{ Project types } & Flood control & 83 & 3.19 & 2.53 & 34.71 \\
\hline & Transportation & 236 & 1.05 & 6.25 & 36.22 \\
\hline & Utilities & 44 & 1.02 & 0.00 & 39.70 \\
\hline \multirow{3}{*}{ Project size } & Less than $\$ 1$ million & 135 & -11.23 & 0.00 & 43.37 \\
\hline & $\$ 1$ million to $\$ 5$ million & 128 & 4.99 & 6.25 & 33.39 \\
\hline & Greater than $\$ 5$ million & 100 & 14.35 & 14.82 & 20.52 \\
\hline \multirow{2}{*}{ Project construction duration } & Less than 1 year & 279 & -4.56 & 0.00 & 38.12 \\
\hline & Greater than 1 year & 84 & 21.79 & 19.92 & 17.87 \\
\hline \multirow{2}{*}{ Project completion year } & 1991 to 2000 & 185 & 4.23 & 1.96 & 29.02 \\
\hline & 2001 to 2008 & 178 & -1.27 & 7.05 & 42.35 \\
\hline Total projects & & 363 & 1.54 & 5.06 & 36.23 \\
\hline
\end{tabular}

TABLE 6: Test of homogeneity.

\begin{tabular}{lcc}
\hline Metrics & Levene's statistic & Significance \\
\hline Factor: project types & & \\
$\quad$ Construction cost overrun & 3.117 & 0.045 \\
$\quad$ Construction schedule overrun & 0.175 & 0.840 \\
Factor: project size & & \\
$\quad$ Construction cost overrun & 1.819 & 0.164 \\
$\quad$ Construction schedule overrun & 12.203 & $<0.001^{* *}$ \\
Factor: project construction duration & & \\
$\quad$ Construction cost overrun & 2.871 & 0.091 \\
$\quad$ Construction schedule overrun & 11.174 & $0.001^{* *}$ \\
Factor: project completion year & & \\
$\quad$ Construction cost overrun & 0.781 & 0.377 \\
$\quad$ Construction schedule overrun & 10.756 & $0.001^{* *}$ \\
\hline
\end{tabular}

${ }^{*}$ Statistically significant at alpha level 0.05 .

** Statistically significant at alpha level 0.01 .

of errors in plans and modifications, and $34 \%$ were due to changed conditions in the projects. Weather damages and utility delays were other reasons for cost and time overruns in these projects [6].
The statistical relationship between actual and estimated costs of road construction was investigated by Odeck [2]. In order to determine the project cost overruns, he used 620 Norwegian road construction projects built from 1992 to 1995 to develop a regression model. The dependent variable considered in the study was cost overrun, which was defined as the difference between estimated costs and actual costs, expressed in terms of percentage of estimated costs. The independent variables considered were estimated cost in terms of Norwegian Krone (NOK), completion time, construction year, location, type of the projects, and type of work force employed.

The data analysis showed that the average cost overrun for the sample was $7.9 \%$. The study showed that cost overruns were more predominant in smaller projects than in larger ones. The correlation coefficient between cost overrun and the completion time was 0.356 , and the $P$ value was 0.003 . In addition, the results showed that cost overruns increased within a certain range of completion time, after which they declined. The cost overrun increased until a completion time of about 200 weeks ( 2.7 years) was reached and then fell.

Further, the study found that there was a relationship between the location of the projects and cost overruns. 
TABLE 7: ANOVA results for construction cost and schedule overrun by project types.

\begin{tabular}{lcccc}
\hline Project types & Unit & Mean & $F$ value & $P$ value \\
\hline Construction cost overrun & & & & \\
$\quad$ Flood control & $\%$ & 3.04 & 1.646 & 0.194 \\
Transportation & $\%$ & 3.23 & & 3.020 \\
$\quad$ Utilities & $\%$ & 1.27 & & 0.895 \\
Construction schedule overrun & $\%$ & 3.19 & 0.111 & 3.020 \\
$\quad$ Flood control & $\%$ & 1.05 & & \\
Transportation & $\%$ & 1.02 & & \\
Utilities & $\%$ & & \\
\hline
\end{tabular}

TABLE 8: ANOVA results, construction cost and schedule overruns by project size.

\begin{tabular}{|c|c|c|c|c|c|}
\hline Project types & Unit & Mean & $F$-value & $P$ value & $F$-critical \\
\hline \multicolumn{6}{|l|}{ Construction cost overrun } \\
\hline Less than $\$ 1$ million & $\%$ & 1.67 & & & \\
\hline$\$ 1$ million to $\$ 5$ million & $\%$ & 3.55 & 4.212 & $0.016^{*}$ & 3.020 \\
\hline Greater than $\$ 5$ million & $\%$ & 3.92 & & & \\
\hline \multicolumn{6}{|c|}{ Construction schedule overrun } \\
\hline Less than $\$ 1$ million & $\%$ & -11.23 & & & \\
\hline$\$ 1$ million to $\$ 5$ million & $\%$ & 4.99 & 16.538 & $<0.001^{* *}$ & 3.020 \\
\hline Greater than $\$ 5$ million & $\%$ & 14.35 & & & \\
\hline
\end{tabular}

* Statistically significant at alpha level 0.05 .

${ }^{* *}$ Statistically significant at alpha level 0.01 .

The $P$ value for the relationship was 0.015 . The cost overruns were higher in the projects that were located in mountainous areas than in the projects located in the plains. Neither the type of project nor the type of work force employed to construct the project appeared to make a significant difference in the amount of cost overruns.

Lee [7] estimated cost overruns and their causes in Social Overhead Capital projects in Korea. The author analyzed 161 roads, rails, airports, and ports projects to determine cost overruns and their causes. The cost overrun was calculated as the percentage increase of the construction cost with respect to the estimated cost. The author found that road and rail projects had a maximum cost overrun of $50 \%$. The main causes of cost overruns were changes in the scope, delays during construction, unreasonable estimation and adjustment of project costs, and no practical use for the earned value management system. The author recommended creating an effective, integrated system by redefining total project cost as the total cost throughout the entire life cycle of a project, like planning, design, acquisition, support, and any other costs directly attributable to owning asset, rather than simple construction cost.

Various studies $[4,5,8-10]$ have determined the correlation of project delivery methods-for example, design build (DB) and design bid build (DBB) - with cost and schedule overruns. These studies found that cost and schedule overrun were fewer in $\mathrm{DB}$ projects than in $\mathrm{DBB}$ projects.

In summary, there is continuing interest in the subject of cost and schedule overruns. Findings from the cited studies correlating cost and schedule overrun with project factors are summarized in Table 2. This current study will determine the magnitude of construction cost and schedule overruns in various types and sizes of public work DBB projects. The methodologies used by the authors of the literature reviewed were influential in the processing of data for this study.

\section{Research Methodology}

The methodology used in this study consisted of steps similar to ones used in most of the previous quantitative studies. Generally, the methodology of these types of studies consisted of data collection, data mining, performing statistical tests, and making conclusions based on the statistical results. Jahren and Ashe [1], Odeck [2], Roth [4], Konchar and Sanvido [5], Hale et al. [9], and Shrestha et al. [8] used similar methodologies to conduct their studies regarding project cost and schedule overruns. The steps used in this study are described below.

3.1. Data Collection and Description. The data for this study are from DBB projects completed by CCDPW in Nevada during the period from 1991 to 2008 [11]. CCPWD has an organized method of recording construction project data. When a project is completed and the final settlement affidavit has been signed by the contractor, signifying that the claim of retention has been settled, the document is sent through the Clark County Recorder's Office to provide the legal, public proof of settlement. Once the affidavit has been recorded and official recording stamps have been affixed, a receipt is returned to the Construction Management Division of the Public Works Department to be included in the rest of the 
TABLE 9: Post hoc analysis for construction cost and schedule overruns by project size.

\begin{tabular}{|c|c|c|c|c|c|c|}
\hline \multirow{2}{*}{ Project size } & \multicolumn{2}{|c|}{ Less than $\$ 1 \mathrm{M}$} & \multicolumn{2}{|c|}{$\$ 1 \mathrm{M}$ to $<\$ 5 \mathrm{M}$} & \multicolumn{2}{|c|}{ Greater than $\$ 5 \mathrm{M}$} \\
\hline & Mean difference & $P$ value & Mean difference & $P$ value & Mean difference & $P$ value \\
\hline \multicolumn{7}{|l|}{ Construction cost overrun } \\
\hline Less than $\$ 1$ million & - & - & 1.88 & 0.054 & 2.26 & $0.026^{*}$ \\
\hline$\$ 1-\$ 5$ million & 1.88 & 0.054 & - & - & 0.38 & 0.902 \\
\hline Greater than $\$ 5$ million & 2.26 & $0.026^{*}$ & 0.38 & 0.902 & - & - \\
\hline \multicolumn{7}{|c|}{ Construction schedule overrun } \\
\hline Less than $\$ 1$ million & - & - & 16.23 & $0.001^{* *}$ & 25.59 & $<0.001^{* *}$ \\
\hline$\$ 1-\$ 5$ million & 16.23 & $0.001^{* *}$ & - & - & 9.36 & 0.109 \\
\hline Greater than $\$ 5$ million & 25.59 & $<0.001^{* *}$ & 9.36 & 0.109 & - & - \\
\hline
\end{tabular}

${ }^{*}$ Statistically significant at alpha level 0.05 .

${ }^{* *}$ Statistically significant at alpha level 0.01 .

TABLE 10: ANOVA results, construction cost and schedule overruns by project duration.

\begin{tabular}{lcccc}
\hline Project construction duration & Unit & Mean & $F$-value & $P$ value \\
\hline Construction cost overrun & & & & \\
$\quad$ Less than 1 year & $\%$ & 2.46 & 6.853 & $0.009^{* *}$ \\
$\quad$ More than 1 year & $\%$ & 4.59 & & 3.867 \\
Construction schedule overrun & $\%$ & -4.56 & 37.585 & $<0.001^{* *}$ \\
$\quad$ Less than 1 year & $\%$ & 21.79 & 3.867 \\
$\quad$ More than 1 year & $\%$ & & \\
\hline
\end{tabular}

* Statistically significant at alpha level 0.05 .

${ }^{* *}$ Statistically significant at alpha level 0.01 .

project documents and is prepared for archiving. Archiving is done by scanning all of the project documents and drawings into the Global 360 KoVIS database. The paper copies are then destroyed, due to shortages in physical storage space.

To retrieve the data for each project, certain information is required. Each project can be accessed either by project numbers or by bid numbers. For this study, bid numbers were used to retrieve the data through the County Global 360 KoVIS database system. The data, available in public domain, were gathered by the authors.

The data retrieved from the database for this study included the engineer's estimate with bid abstract; the completion memorandum to the Clark County Purchasing Office, including the bid cost, final cost, and change order costs, if applicable; the bid construction time and the final construction time; the notice to proceed (NTP) date; and the substantial completion date. With older projects, final pay applications for retention release were substituted for bid abstracts when the abstract could not be found. Every effort was made to keep the type of documents consistent for each project; however, there were exceptions, which did not affect the accuracy of the data. The list of variables that were gathered for this study is shown in Table 3.

363 DBB projects contained enough data to be useful for this study. The projects used for this study covered a period of 18 years and fell into three categories: (1) transportation (236), (2) utilities (44), and (3) flood control (83). These categories included a variety of projects, both in the scope of work and the dollar amount, that were representative of the work performed by CCDPW. The magnitudes of the cost and schedule overruns were compared based on project types, size of projects based on construction cost and duration, and project completion years. The project types and size considered for this study as well as the findings of previous research related to these factors are described below.

3.2. Project Types. The projects were subdivided into three types, namely, flood control, transportation, and utilities projects, which are the major types of construction CCDPW generally undertakes. Previous research determined that cost overruns were correlated with the project types $[3,7]$. However, Odeck [2] found no relationship between these two variables.

3.3. Construction Cost. The final construction cost was used to divide the projects into different sizes. The project size was divided into three categories: (1) small projects costing below $\$ 1$ million, (2) medium projects costing between \$1 million and $\$ 5$ million, and (3) large projects costing more than \$5 million. Randolph et al. [3] and Odeck [2] determined that the cost overrun was inversely correlated with the size of the project. However, findings of Jahren and Ashe [1] were exactly the opposite.

3.4. Construction Duration. The projects were divided into two groups based on the construction duration. One group of projects had construction durations of less than one year (234 working days) and the other group of projects had construction durations of more than one year (234 working 
TABLE 11: ANOVA results for construction cost and schedule overruns by project completion year.

\begin{tabular}{lcccc}
\hline Project completion year & Unit & Mean & $F$-value & $P$ value \\
\hline Construction cost overrun & & & & \\
$\quad$ From 1991 to 2000 & $\%$ & 2.66 & 0.721 & 0.396 \\
$\quad$ From 2001 to 2008 & $\%$ & 3.25 & & 3.867 \\
Construction schedule overrucal & & & & \\
$\quad$ Less than 1 year & $\%$ & 4.23 & 2.093 & 3.867 \\
$\quad$ More than 1 year & $\%$ & -1.27 & & \\
\hline
\end{tabular}

days). Odeck [2] found that the cost overruns increased as the completion duration increased up to a certain time (200 weeks); after that, the cost overruns started decreasing.

3.5. Construction Completion Year. In addition, the projects were subdivided into two groups, based on the construction completion year. One group of projects was completed from 1991 to 2000, and the other group of projects was completed after 2000. Vidalis and Najafi [6] determined that the cost and schedule overruns were lower in the recent road projects (2000 and 2001) compared to previous road projects (from 1996 to 1999). All four project factors considered for the analysis were categorical variables.

3.6. Statistical Analysis. The performance metrics analyzed for this study were construction cost and schedule overrun. Equation (1) were used to calculate construction cost and schedule overrun, respectively. Consider

\section{Construction Cost Overrun}

$$
\begin{aligned}
& =((\text { Actual Construction Cost } \\
& \quad-\text { Award Construction Cost }) \\
& \left.\quad \times(\text { Award Construction Cost })^{-1}\right) \times 100
\end{aligned}
$$

Construction Schedule Overrun

$$
\begin{aligned}
& =((\text { Actual Construction Duration } \\
& \quad-\text { Award Construction Duration }) \\
& \left.\quad \times(\text { Award Construction Duration })^{-1}\right) \times 100 .
\end{aligned}
$$

In order to establish a more direct comparison of the projects, the costs needed to be adjusted to a same-year index. The final construction cost for each project was adjusted to 2012 values, using national conversion factors published in the Engineering News Record [12]. No adjustment was done to account for periods of high cost overruns for fuel. To change earlier project costs to 2012 values, the figures for the projects' final construction costs were each multiplied by these factors to arrive at the adjusted final construction costs used in the analysis. The adjusted final construction cost was used to categorize the project size.

Once the construction costs and schedule overruns were calculated, these were entered into the Statistical Package for Social Sciences (SPSS) along with factors for processing. The data were analyzed using one-factor analysis of variance (ANOVA) tests in order to compare the sample means and determine the main effects of factors on construction cost and schedule overruns. The factors considered were categorical variables; therefore, the ANOVA test was used to determine the effect of these variables. The confidence level for the analysis was set at $95 \%$, because the statistical analysis done within this range is considered to be acceptable in the construction community. The ANOVA assumed a null hypothesis that the means $(\mu)$ of the different groups of projects were equal $\left(\mu_{1}=\mu_{2}=\mu_{3}=\cdots\right)$. For the null hypothesis to be false, the $P$ value needed to be less than or equal to 0.05 . Given that the null hypothesis was true, the $P$ value represented the probability of observing a random sample that was at least as large as the observed sample. If the $P$ value was below 0.05 , the difference in the means would be considered statistically significant [13].

\section{Results}

The statistical tests determined the descriptive statistics of the dependent variables and showed whether the sample means of various groups were statistically different. The results of these tests are described below.

4.1. Descriptive Statistics. Table 4 presents the descriptive statistics of the construction cost overruns by project factors. The mean construction cost overrun for the sample projects was $2.95 \%$. The median construction cost overrun for the entire projects was zero. The standard deviation for all projects was low. The analysis showed that the mean construction cost overrun for transportation projects was higher than the mean for flood control and utilities projects. Based on the size of projects, the projects with construction cost greater than $\$ 5$ million had a higher cost overrun than the projects costing from $\$ 1$ million to $\$ 5$ million and less than $\$ 1$ million. Projects costing less than $\$ 1$ million had the least construction cost overrun (1.67\%).

Categorizing the projects based on construction duration, the projects that took more than one working year to complete had a higher cost overrun than projects that took less than one working year to complete. The standard deviations for these two groups of projects were low. Similarly, the mean construction cost overrun was higher on projects that were completed after 2000 than that of projects completed by 2000 (Table 4). 
Table 5 presents the descriptive statistics of construction schedule overruns by project factors. The mean and median construction schedule overruns for all projects were $1.54 \%$ and $5.06 \%$, respectively. The standard deviation for all projects was high. The construction schedule overruns had higher variability than the construction cost overruns. The analysis showed that the mean construction schedule overrun for flood control projects was higher than the mean for transportation and utilities projects. Based on the size of projects, the projects with construction cost less than \$1 million had lower schedule overrun than the other project size categories. The projects costing more than $\$ 5$ million had the highest mean construction schedule overrun (14.35\%). Categorizing the projects based on construction duration, the projects that were completed in more than one working year had higher schedule overruns than the projects completed in less than one working year. The standard deviations for both of these groups was high. Similarly, the mean construction schedule overruns was higher for projects that were completed by 2000 than for projects that were completed after 2000 .

4.2. Results of One-Factor Analysis of Variance (ANOVA) of Cost and Schedule Overruns. An ANOVA test was conducted to determine the significant factors affecting the construction costs and schedule overruns. To use the ANOVA test, four assumptions needed to be fulfilled:

(1) the dependent variables needed to be interval or ratio scaled;

(2) the samples needed to be randomly selected from the population;

(3) the dependent variables for all the groups needed to be normally distributed;

(4) the variances of the population distribution for all the groups needed to be equal.

The first, second, and third assumptions were found to hold true in this sample. Levene's test was conducted to determine if the samples had equal variances according to assumption 4 . The null hypothesis for this test was that the samples had equal variances. The null hypothesis would have been rejected if the significance level of this test was less than 0.05 .

The test results showed that only construction schedule overrun on three occasions had significance levels less than 0.05 (Table 6). Therefore, only construction schedule overrun did not have equal variances. If the scores in the population were normally distributed, then the results of the ANOVA test would not be affected, because the $F$ statistic is quite robust against violations of this assumption; this was found to hold true in this sample [14].

4.3. Construction Cost and Schedule Overruns by Project Type. Table 7 shows the mean values of construction cost and schedule overruns for different types of projects with their $F$-value, $P$ value, and $F$-critical value. The means of cost and schedule overruns for flood control, transportation, and utilities projects were not different, statistically. The $P$ value for these two metrics was larger than 0.05 . Therefore, it could not be concluded, statistically, that the sample means were different. In fact, for this sample, evidence tended to indicate that the construction cost overrun for transportation projects was higher than for flood control and utilities projects and construction schedule overrun for flood control was higher than for transportation and utilities projects.

4.4. Construction Cost and Schedule Overruns by Project Size. Table 8 shows the mean values of construction cost and schedule overruns for different sizes of projects, along with their $F$-value, $P$ value, and $F$-critical value. The significance test conducted on construction cost and schedule overruns showed that the $P$ value was less than 0.05 . Therefore, the null hypothesis could be rejected with statistical certainty, confirming the difference in the sample means. It could be concluded that, in this sample, the construction cost and schedule overruns for one of these types of project sizes were different than the construction cost and schedule overruns for other types of project sizes.

Tukey's post-hoc analysis was conducted to determine differences in group means, as shown in Table 9. The analysis shows that the construction cost overrun of projects costing less than $\$ 1$ million was statistically lower than that of projects costing greater than $\$ 5$ million. Similarly, for this sample, the construction schedule overrun of projects costing less than $\$ 1$ million was statistically lower than that of projects costing greater than $\$ 1$ million. The analysis showed that for this sample, the construction cost and schedule overruns of larger projects were statistically higher than those for smaller projects.

\subsection{Construction Cost and Schedule Overruns by Construction} Duration. Table 10 shows the mean values of construction cost and schedule overruns for projects with construction duration of less than one working year and projects with more than one working year, along with their $F$-value, $P$ value, and $F$-critical value. The significance test conducted on construction cost and schedule overruns showed that the $P$ value was less than 0.05 . Therefore, the null hypothesis could be rejected with statistical certainty, confirming the difference in sample means. In this sample, it was concluded that the construction cost and schedule overruns of projects with construction duration of less than one year were lower than those for projects with construction duration of more than one year.

4.6. Construction Cost and Schedule Overruns by Completion Year. Table 11 shows the mean values of construction cost and schedule overruns for projects completed from 1991 to 2000 and projects completed from 2001 to 2008, along with their $F$-value, $P$ value, and $F$-critical value. The significance test conducted on construction cost and schedule overruns showed that the $P$ value was greater than 0.05 . The null hypothesis could not be rejected with statistical certainty. In this sample, this confirmed that the construction cost and schedule overruns for projects completed between 1991 and 
2000 were statistically equal to the construction cost and schedule overruns for projects completed between 2001 and 2008.

\section{Limitations}

It should be noted that care should be taken when extending the results of this study to other types of projects and organizations because of the homogeneity of the projects, the way the public sector organizations operate, and projects constructed in limited geographical locations. The findings of this study were determined from DBB public projects costing less than $\$ 50$ million, constructed by CCDPW. The sample projects consisted of both new and reconstruction projects.

\section{Conclusions and Recommendations}

This study collected data and analyzed 363 homogenous projects of CCDPW construction projects. All of the projects were administered by the same organization by using the DBB project delivery method. These projects were diversified in terms of cost, construction duration, construction completion year, and project types. The analysis showed that, the data for cost and schedule overruns were homogenous when separated, based on four project factors: project types, project size, construction duration, and completion year.

The results showed that two out of four factors considered in this analysis had significant correlation with construction cost and schedule overruns. The sample data showed that cost and schedule overruns increased as the project size and construction duration increased. One possible explanation for this finding was that as, the project size increased, the complexity of the project increased, thus increasing cost as well as schedule overruns. Similarly, when the project construction duration increased, there was a greater chance of disruption in the project, which in turn increased the cost and schedule overruns of projects. The results regarding the relationship between cost overrun and project size were similar to previous research conducted by Jahren and Ashe [1].

This study could not find any relationship between cost and schedule overruns with project types and project completion year. However, studies conducted by Randolph et al. [3] and Lee [7] found a relationship between the cost overrun and types of projects. One of the possible explanations for not finding a relationship between cost and schedule overruns with project completion year is that there were no significant changes of CCDPW project management practices for public work projects during the study period (1991 to 2008).

In order to validate these findings, further research is recommended with projects from different geographical locations and owners. Moreover, it is recommended that other factors should to be identified that contribute to construction cost and schedule overruns in public work projects.

\section{Acknowledgment}

The authors acknowledge construction division staff of Clark County Public Work Department, Nevada, for providing the completed projects' cost and schedule data. This study would not have been possible without their contributions.

\section{References}

[1] C. T. Jahren and A. M. Ashe, "Predictors of cost-overrun rates," Journal of Construction Engineering and Management, vol. 116, no. 3, pp. 548-552, 1990.

[2] J. Odeck, "Cost overruns in road construction-what are their sizesand determinants?" Transport Policy, vol. 11, no. 1, pp. 4353, 2004

[3] D. A. Randolph, K. Rajendra, and J. J. Campfield, "Using risk management techniques to control contract costs," Journal of Management in Engineering, vol. 3, no. 4, pp. 314-324, 1987.

[4] M. Roth, An empirical analysis of United States Navy design/build contracts [M.S. thesis], University of Texas, Austin, Tex, USA, 1995.

[5] M. Konchar and V. Sanvido, "Comparison of U.S. project delivery systems," Journal of Construction Engineering and Management, vol. 124, no. 6, pp. 435-444, 1998.

[6] S. M. Vidalis and F. T. Najafi, "Cost and time overruns in highway construction," in Proceedings of the 4th Transportation Specification. Conference of the Canadian Society for Civil Engineering, pp. 2799-2808, Montreal, Quebec, Canada, June 2002.

[7] J.-K. Lee, "Cost overrun and cause in Korean social overhead capital projects: roads, rails, airports, and ports," Journal of Urban Planning and Development, vol. 134, no. 2, pp. 59-62, 2008.

[8] P. P. Shrestha, G. C. Migliaccio, J. T. O'Connor, and G. E. Gibson Jr., "Benchmarking of large design-build highway projects one-to-one comparison and comparison with design-bid-build projects," Transportation Research Record, no. 1994, pp. 17-25, 2007.

[9] D. R. Hale, P. P. Shrestha, G. E. Gibson Jr., and G. C. Migliaccio, "Empirical comparison of design/build and design/bid/build project delivery methods," Journal of Construction Engineering and Management, vol. 135, no. 7, pp. 579-587, 2009.

[10] T. R. Warne, Design Build Contracting for Highway Projects: A Performance Assessment, Tom Warne \& Associates, LLC, 2005.

[11] L. Burns, Analyzing cost and schedule growth in Public Works Projects [M.S. thesis], University of Nevada, Las Vegas, Nev, USA, 2008.

[12] Engineering News-Record (ENR), General Contracting Cost Book, vol. 1, McGraw-Hill Construction, New York, NY, USA, 2012.

[13] E. Weinstein, "Wolfram math world, the web's most extensive mathematics resource," 2012, http://mathworld.wolfram .com/ANOVA.html.

[14] T. Hill and P. Lewicki, Statistics-Methods and Applications, Stat Soft, Inc, Tulsa, Okla, USA, 2006. 

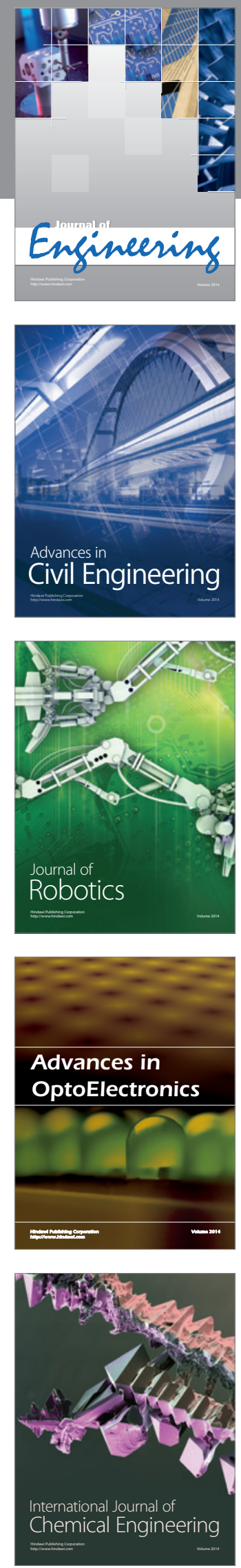

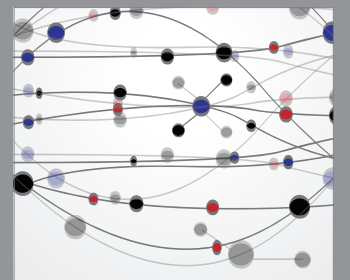

The Scientific World Journal
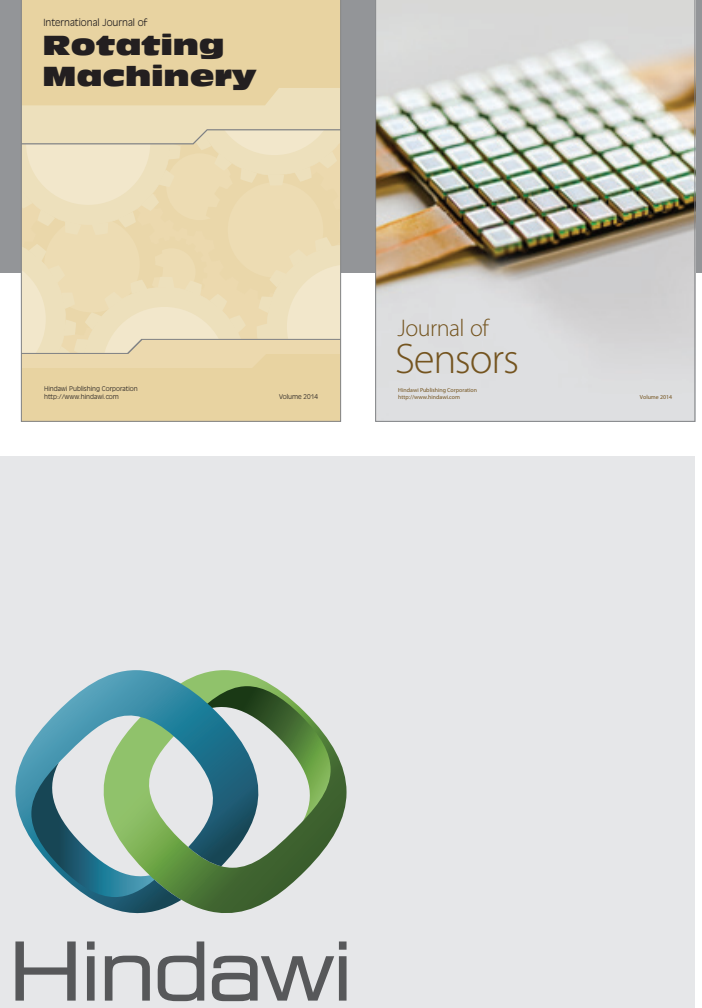

Submit your manuscripts at http://www.hindawi.com
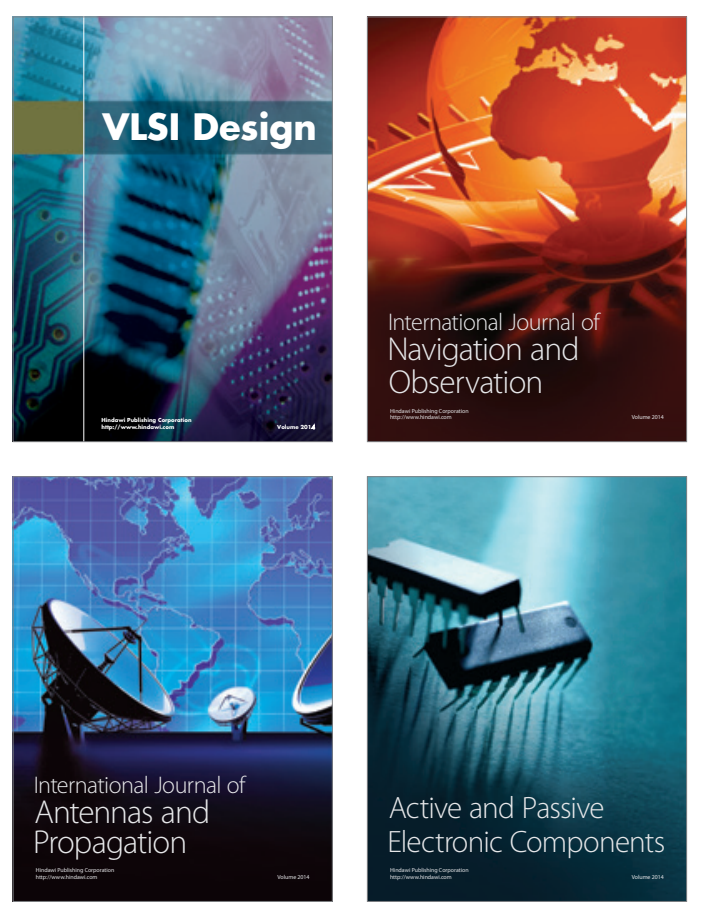
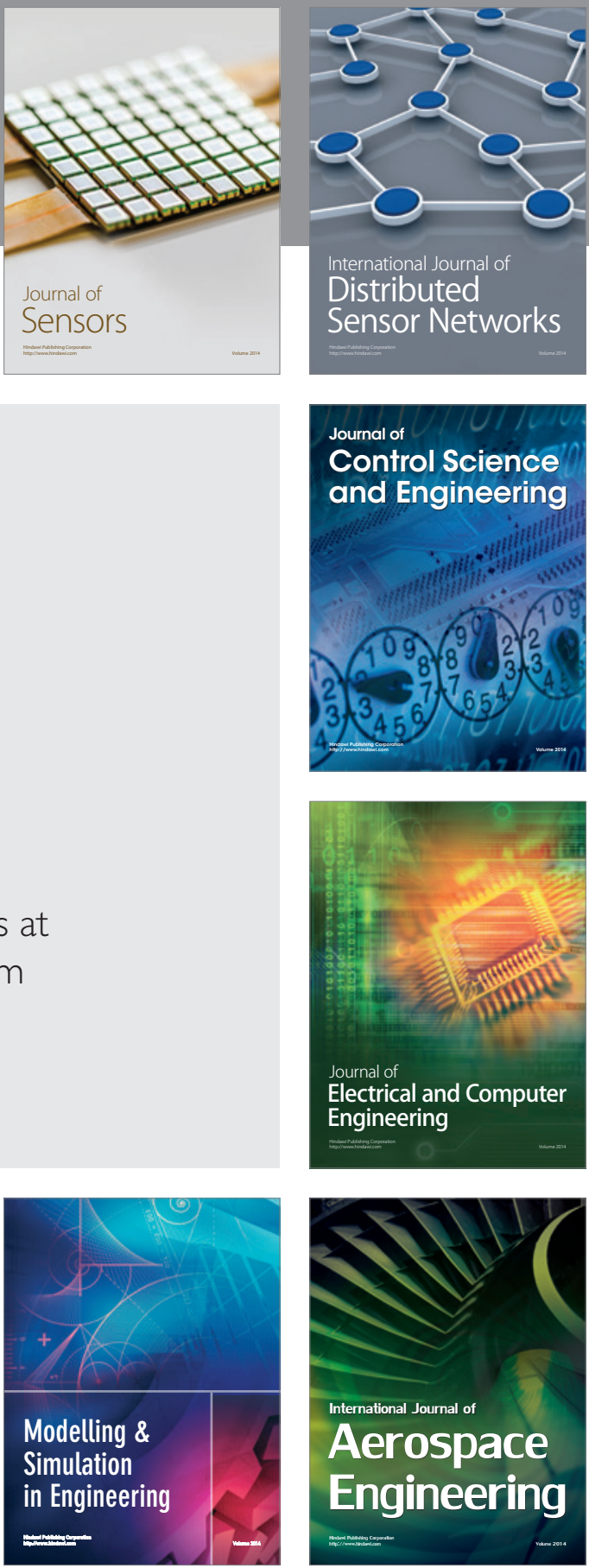

Journal of

Control Science

and Engineering
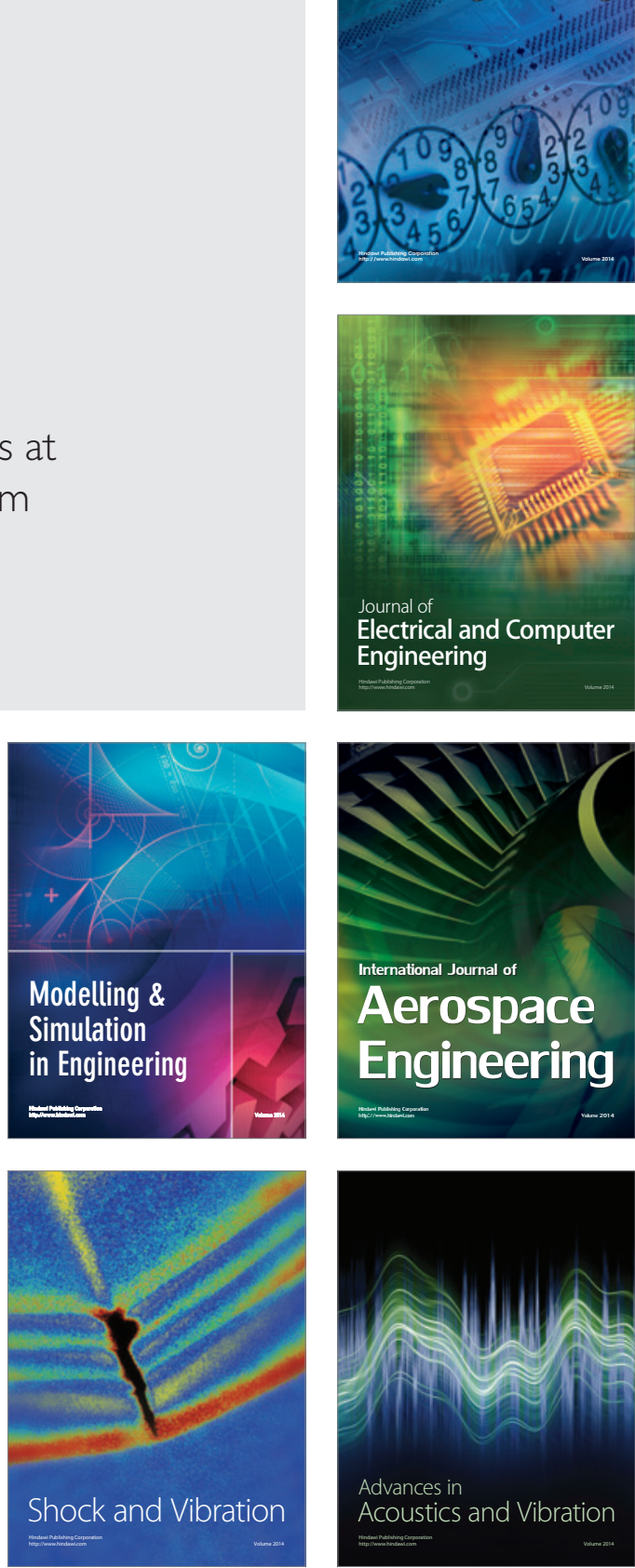